\title{
AKUNTANSI PENDAPATAN RETRIBUSI PEMAKAIAN KEKAYAAN DAERAH PADA BADAN PENGELOLA PENDAPATAN DAERAH PROVINSI JAWA TENGAH
}

\author{
Lenny Nur Fajriyah, Adilistiono \\ Jurusan Akuntansi, Politeknik Negeri Semarang \\ Jl.Prof.H.Sudarto, SH, Tembalang, Kotak Pos 6199/SMS Semaran 50061
}

\begin{abstract}
This research aims to determine the accounting process starting from transactions by supporting documents to present them into financial statements. As well as to determine the suitability of processing supporting documents used by the Central Java Province Revenue Management Agency and the accounting treatment of revenue from the use of regional wealth. The method used is the description and exposition method. The description method is used to explain the general description of the Central Java Province Regional Revenue Management Agency, the vision and mission, organizational structure, and duties and exposition method are used to explain the application of accrual basis on the recognition, measurement, presentation and disclosure of Regional Property Usage levies on Central Java Provincial Revenue Management Agency. The results of this final project writing are showing the supporting documents of the Central Java Province Regional Revenue Management Agency has been processed correctly, besides knowing the recognition, measurement and presentation of revenue revenues from the regional wealth management levies in Central Java Province.
\end{abstract}

Keywords:Retribution, Regional Wealth, Retribution Income, Revenue Recognition, Income Measurement, Income Presentation.

\begin{abstract}
Abstrak: Penelitian ini bertujuan untuk menentukan proses akuntansi mulai dari transaksi dengan dokumen pendukung untuk mempresentasikannya dalam laporan keuangan. Serta untuk menentukan kesesuaian pemrosesan dokumen pendukung yang digunakan oleh Badan Pengelolaan Pendapatan Provinsi Jawa Tengah dan perlakuan akuntansi pendapatan dari penggunaan kekayaan daerah. Metode yang digunakan adalah metode deskripsi dan eksposisi. Metode deskripsi digunakan untuk menjelaskan gambaran umum Badan Pengelolaan Pendapatan Daerah Provinsi Jawa Tengah, visi dan misi, struktur organisasi, dan tugas serta metode eksposisi yang digunakan untuk menjelaskan penerapan dasar akrual pada pengakuan, pengukuran, penyajian dan pengungkapan pungutan Penggunaan Properti Daerah di Badan Pengelolaan Pendapatan Provinsi Jawa Tengah. Hasil penulisan tugas akhir ini menunjukkan dokumen pendukung Badan Pengelolaan Pendapatan Daerah Provinsi Jawa Tengah telah diproses dengan benar, selain mengetahui pengakuan, pengukuran dan penyajian pendapatan pendapatan dari retribusi pengelolaan kekayaan daerah di Provinsi Jawa Tengah.
\end{abstract}

Kata kunci: Retribusi, Kekayaan Daerah, Pendapatan Retribusi, Pengakuan Pendapatan, Pengukuran Pendapatan, Penyajian Pendapatan. 


\section{PENDAHULUAN \\ Latar Belakang}

Retribusi Daerah merupakan salah satu elemen penting dalam menunjang Pendapatan Asli Daerah karena mampu memberikan kontribusi yang cukup besar untuk kelangsungan Pemerintah Daerah. Undang-Undang Nomor 28 Tahun 2009 tentang Pajak Daerah dan Retribusi Daerah menyatakan bahwa Retribusi Daerah dapat dikelompokkan menjadi 3 (tiga) bagian, yaitu retribusi jasa umum, retribusi jasa usaha, dan retribusi perizinan tertentu. Pada masing-masing kelompok retribusi daerah, terdiri atas berbagai macam retribusi yang jenisnya sangat banyak dan beragam.

Badan Pengelola Pendapatan Daerah Provinsi Jawa Tengah mengelola salah satu jenis Retribusi, yakni Retribusi Jasa, Usaha Retribusi Pemakaian Kekayaan Daerah. Menurut Peraturan Daerah Provinsi Jawa Tengah No.1 Tahun 2011 Tentang Retribusi Daerah Provinsi Jawa Tengah, Retribusi Pemakaian Kekayaan Daerahdipungut retribusi sebagai pembayaran atas pelayanan penggunaan, pemakaian dan pemanfaatan kekayaan barang-barang bergerak dan/atau tidak bergerak serta fasilitas-fasilitas penunjang lainnya yang diberikan oleh Pemerintah Daerah. Pemungutan tersebut harus sesuai Undang-Undang yang berlaku mulai dari penawaran, pencatatan, dan penjurnalan.Dalam prosesnya, pencatatan pemungutan dibantu dengan dokumen pendukung yakni Surat Ketetapan Retribusi Daerah (SKRD), Tanda Bukti Pembayaran (TBP), dan Surat Tanda Setoran (STS).Apabila terjadi kesalahan pencatatan,pemungutan bahkan pelaporan akan berimbas pada laporan keuangan. Laporan keuangan digunakan sebagai dasar untuk mengevaluasi pelaksanaan keuangan yang lalu dalam rangka mengambil keputusan ekonomi yang diperlukan oleh pihak yang berkaitan untuk masa yang akan datang. Laporan keuangan juga digunakan untuk membandingkan realisasi pendapatan dan belanja dengan anggaran yang telah ditetapkan, mengevaluasi efektifitas dan efisiensi suatu entitas pelaporan dan membantu menentukan ketaatannya terhadap peraturan perundang-undangan.

Akan tetapi, Dalam pelaksanaan pelaporan pendapatan belum optimal khususnya pada pelaporan dokumen pendukung retribusi pemakaian kekayaan daerah yang belum sesuai peraturan yang ada. Apabila dalam pelaporannya belum optimal maka akan mengakibatkan perbedaan dalam Laporan Keuangan terutama pada Laporan Realisasi Anggaran dan Laporan Operasional. Setiap akun pembentuk laporan keuangan, khususnya mengenai Pendapatan Retribusi Pemakaian Kekayaan Daerah harus diperhitungkan secara benar dan tepat agar menghasilkan laporan keuangan yang relevan dan dapat dipertanggungjawabkan. Perhitungan pendapatan tersebut harus memperhatikan perlakuan, pengakuan, pengukuran, dan penyajian retribusi pemakaian kekayaan daerah sesuai peraturan yang telah ada.

\section{Rumusan Masalah}

Berdasarkan latar belakang diatas, maka masalah yang dapat dirumuskan adalah sebagai berikut:

1. Bagaimana pengakuan, pengukuran, penyajian serta pengungkapan pendapatan Retribusi Pemakaian Kekayaan Daerah dengan basis akrual pada Badan Pengelola Pendapatan Daerah?

2. Apakah dokumen pendukung pendapatan Retribusi Daerah Pemakian Kekayaan Daerah telah diproses secara benar dalam jurnal khusus pendapatan? 


\section{Retribusi Pemakaian Kekayaan Daerah} Menurut Peraturan Daerah Nomor 1 Tahun 2011 Tentang Retribusi Daerah Provinsi Jawa Tengah menjelaskan pengertian dari Retribusi Daerah yang selanjutnya disebut retribusi adalah pungutan daerah sebagai pembayaran atas jasa atau pemberian izin tertentu yang khusus disediakan dan/atau diberikan oleh pemerintah daerah untuk kepentingan orang pribadi atau badan.

Menurut Peraturan Daerah Jawa Tengah Nomor 1 Tahun 2011 Tentang Retribusi Daerah menjelaskan Retribusi Pemakaian Kekayaan Daerah dipungut retribusi sebagai pembayaran atas pelayanan penggunaan, pemakaian dan pemanfaatan kekayaan barang-barang bergerak dan/atau tidak bergerak serta fasilitas-fasilitas penunjang lainnya yang diberikan oleh Pemerintah Daerah.

\section{Obyek, dan Subyek Retribusi Pemakaian Kekayaan Daerah}

Menurut Peraturan Daerah Jawa Tengah Nomor 1 Tahun 2011 Tentang Retribusi Daerah menjelaskan Objek retribusi pemakaian kekayaan daerah adalah setiap pelayanan penggunaan dan pemakaian kekayaan yang dimiliki dan/atau dikuasai Pemerintah Daerah. Objek retribusi pemakaian kekayaan daerah meliputi :

1. Penggunaan, pemakaian, pemanfaatan tanah;

2. Pemakaian bangunan gedung dan/atau aula;

3. Pemakaian asrama dan/atau kamar;

4. Pemakaian kendaraan;

5. Pemakaian alat labortatorium, alat berat/alat besar dan peralatan bengkel.

Subyek Retribusi Pemakaian Kekayaan Daerah Menurut Peraturan Daerah Jawa Tengah Nomor 1 Tahun 2011 Tentang Retribusi Daerah menjelaskan retribusi pemakaian kekayaan daerah adalah orang pribadi atau badan yang menggunakan, memakai dan memanfaatkan kekayaan daerah.

\section{Tarif Retribusi Pemakaian Kekayaan Daerah}

Berikut ini penetapan tarif Retribusi Pemakaian Kekayaan Daerah menurut Peraturan Gubernur Provinsi Jawa Tengah Nomor 20 Tahun 2015 yakni:

\section{Tabel 1}

Tarif Retribusi Pemakaian Kekayaan Daerah

\begin{tabular}{|l|l|l|l|l|}
\hline \multirow{2}{*}{ No. } & Jenis Kekayaan Daerah & Susunan Pemakaian & $\begin{array}{l}\text { Tesarnya } \\
\text { Retribusi(Rp) }\end{array}$ & Keterangan \\
\cline { 3 - 5 } a. & $\begin{array}{l}\text { Pemanfaatan tanah } \\
\text { dan/atau bangunan }\end{array}$ & $\begin{array}{l}\text { tarif sesuai } \\
\text { harga umum } \\
\text { setempat \& } \\
\text { dituangkan } \\
\text { dalam } \\
\text { perjanjian }\end{array}$ & \\
\hline b. & $\begin{array}{l}\text { Pemakaian ruangan untuk } \\
\text { Work Shop, kantin, dan } \\
\text { fotocopy }\end{array}$ & per m2/bulan & 30.000 & \\
\hline
\end{tabular}

(Sumber :Peraturan Gubernur Provinsi Jawa Tengah Nomor 20 Tahun 2015) 


\section{Akuntansi Pendapatan Laporan Operasional \\ Menurut Peraturan Pemerintah} Nomor 71 Tahun 2010 Tentang Standar Akuntansi Pemerintahan menjelaskan akuntansi adalah proses identifikasi, pencatatan, pengukuran, pengklasifikasian, pengikhtisaran transaksi dan kejadian keuangan, penyajian laporan serta penginterpretasian atas hasilnya. Dalam Peraturan Pemerintah Nomor 71 Tahun 2010 Tentang Standar Akuntansi Pemerintahan, dikenal 2 (dua) istilah pendapatan yakni Pendapatan Laporan Realisasi Anggaran (Pendapatan-LRA) dan Pendapatan Laporan Operasional (Pendapatan-LO). Pendapatan-LO adalah hak pemerintah pusat/daerah yang diakui sebagai penambah ekuitas dalam periode tahun anggaran yang bersangkutan dan tidak perlu dibayar kembali. Sedangkan Pendapatan-LRA adalah semua penerimaan Rekening Kas Umum Negara/Daerah yang menambah Saldo Anggaran Lebih dalam periode tahun anggaran yang bersangkutan yang menjadi hak pemerintah, dan tidak perlu dibayar kembali oleh pemerintah.

\section{Dokumen Pendukung yang digunakan}

Menurut Peraturan Gubernur Nomor 45 Tahun 2014 Tentang Kebijakan Dan Sistem Akuntansi Pemerintah menyebutkan dokumen sumber yang digunakan pada Akuntansi Pendapatan-LO dan Pendapatan-LRA meliputi :

a. SKR (Surat Ketetapan Retribusi)

b. Bukti Pembayaran

Menurut Abdul Hafiz Tanjung (2015:148) mengatakan dokumen sumber untuk menjurnal Pendapatan-LO adalah Tanda Bukti Pembayaran.Jadi bukti pembayaran salah satunya adalah Tanda Bukti Pembayaran (TBP).

c. Surat Tanda Setoran(STS)
Menurut Erlina dkk (2015:123) Surat Tanda Setoran (STS) merupakan dokumen yang diselenggarakan Bendahara Penerimaan atau Pejabat Penatausahaan Keuangan Daerah untuk menyetor penerimaan daerah.

\section{Perlakuan Pendapatan Laporan Operasional \\ Pengakuan Pendapatan Laporan Operasional \\ Menurut Peraturan Pemerintah} Nomor 71 Tahun 2010 Tentang Standar Akuntansi Pemerintahan mengatakan pengakuan adalah proses penetapan terpenuhinya kriteria pencatatan suatu kejadian atau peristiwa dalam catatan akuntansi sehingga akan menjadi bagian yang melengkapi unsur aset, kewajiban, ekuitas, pendapatanLRA, belanja, pembiayaan, pendapatanLO, dan beban, sebagaimana akan termuat pada laporan keuangan entitas pelaporan yang bersangkutan. Pendapatan-LO diakui pada saat:

1. Timbulnya hak atas pendapatan,

2. Pendapatan direalisasi, yaitu adanya aliran masuk sumber daya ekonomi.

\section{Pengukuran Pendapatan Laporan Operasional \\ Menurut Peraturan Pemerintah} Nomr 71 Tahun 2010 Tentang Standar Akuntansi Pemerintahan Pengukuran adalah proses penetapan nilai uang untuk mengakui dan memasukkan setiap pos dalam laporan keuangan. Pengukuran pos-pos dalam laporan keuangan menggunakan nilai perolehan historis. Menurut Peraturan Gubernur Jawa Tengah Nomor 120 Tahun 2016 tentang Kebijakan Akuntansi Pemerintah Daerah pengukuran Pendapatan-LO dilaksanakan berdasarkan azas bruto, yaitu dengan membukukan pendapatan bruto, dan tidak mencatat jumlah netonya (setelah dikompensasikan dengan pengeluaran). Dan pemungutan pendapatan yang dipersamakan dengan surat ketetapan 
dapat dicatat secara rekapitulasi harian berdasarkan kas yang diterima.

\section{Penyajian dan Pengungkapan Pendapatan Laporan Operasional \\ Pengungkapan Pendapatan-LO}

Menurut Erlina dkk (2015:121) Pendapatan disajikan berdasarkan jenis pendapatan dalam laporan operasional dan rincian lebih lanjut jenis pendapatan dalam catatan atas laporan keuangan. Sedangkan menurut Peraturan Gubernur Nomor 120 Tahun 2016 Tentang Kebijakan Akuntansi Pemerintah Daerah, penyajian dan pengungkapan Pendapatan Laporan Operasional yaitu :

a. Entitas pemerintah menyajikan pendapatan-LO yang diklasifikasikan menurut sumber pendapatan,

b. Pendapatan-LO disajikan dalam mata uang rupiah.

c. Disamping disajikan pada LO, pendapatan-LO juga harus diungkapkan sedemikian rupa pada CaLK sehingga dapat memberikan semua informasi yang relevan mengenai bentuk dari pendapatanLO.

\section{Penyajian dalam Laporan Realisasi Anggaran}

Menurut Peraturan Pemerintah Nomor 71 Tahun 2010 Tentang Standar Akuntansi Pemerintahan menyatakan Laporan Realisasi Anggaran (LRA) menyediakan informasi mengenai realisasi pendapatan-LRA, belanja, transfer, surplus/defisit-LRA, dan pembiayaan dari suatu entitas pelaporan yang masing-masing diperbandingkan dengan anggarannya. Dalam mengevaluasi keputusan mengenai alokasi sumber-sumber daya ekonomi, akuntabilitas dan ketaatan entitas pelaporan terhadap anggaran.Laporan Realisasi Anggaran (LRA) mencakup pos-pos sebagai berikut:
a. Pendapatan-LRA,
b. Belanja,

c. Transfer,

d. Surplus/defisit-LRA,

e. Penerimaan pembiayaan,

f. Pengeluaran pembiayaan,

g. Pembiayaan neto, dan

h. Sisa lebih/kurang pembiayaan anggaran (SiLPA/SiKPA).

\section{Penyajian dalam Neraca}

Menurut Peraturan Pemerintah Nomor 71 Tahun 2010 Tentang Standar Akuntansi Pemerintah menyatakan Neraca menggambarkan posisi keuangan suatu entitas pelaporan mengenai aset, kewajiban, dan ekuitas pada tanggal tertentu. Pada entitas pelaporannya mengungkapkan setiap pos aset dan kewajiban yang mencakup jumlah-jumlah yang diharapkan akan diterima atau dibayar dalam waktu 12 bulan setelah tanggal pelaporan dan jumlah-jumlah yang diharapkan akan diterima dan dibayar dalam waktu lebih dari 12 (dua belas) bulan. Neraca menyajikan secara komparatif dengan periode sebelumnya pos-pos berikut:

a. Kas dan Setara Kas,

b. Investasi Jengka Pendek,

c. Piutang Pajak dan Bukan Pajak,

d. Persediaan,

e. Investasi Jangka Panjang,

f. Aset Tetap,

g. Kewajiban Jangka Pendek,

h. Kewajiban Jangka Panjang,

i. Ekuitas.

\section{METODOLOGI}

Dalam penyusunan Tugas Akhir yang baik dan benar membutuhkan suatu metodologi agar penulis dapat terarah dan dipaparkan secara urut sehingga dapat memberikan gambaran yang jelas tentang objek atau permasalahan yang disampaikan.

Menurut Sukardi (2011:17) Metodologi diartikan sebagai kegiatan yang secara sistematis, direncanakan oleh para peneliti untuk memecahkan permasalahan yang hidup dan berguna bagi masyarakat, maupun bagi peneliti itu sendiri. 


\section{Klasifikasi Data}

Data memiliki beberapa ciri yang dapat diklasifikasikan menurut kekhususan tertentu, sesuai dengan maksud penelitian ataupun sumber data yang digunakan.Data diklasifikasikan menjadi 2 (dua) yaitu sumber data dan jenis data.

\section{Sumber Data}

Sumber data ada 2 (dua) jenis yaitu :

a. Data Primer

Menurut Wahyu Purhantara (2010:79)

Data Primer adalah data yang diperoleh langsung dari subyek penelitian, dalam hal ini peneliti memperoleh data atau informasi langsung dengan menggunakan instrukmen-intrumen yang telah ditetapkan. Dalam hal ini, data primer diperoleh dari hasil wawancara dengan Staff pada Bagian Keuangan.

b. Data Sekunder

Menurut Wahyu Purhantara (2010:79)

Data sekunder merupakan data atau informasi yang diperoleh secara tidak langsung dari obyek penelitian yang bersifat publik, yang terdiri atas: struktur organisasi data kearsipan, dokumen, laporan-laporan serta bukubuku dan lain sebagainya yang berkenaan dengan penelitian ini.Dalam hal ini, data yang merupakan data sekunder adalah gambaran umum Badan Pengelola Pendapatan Daerah Provinsi Jawa Tengah, Laporan Realisasi Anggaran, Laporan Operasional, Neraca, serta dokumen pembantu retribusi pemakaian kekayaan daerah.

\section{Jenis Data}

Jenis data diklasifikasikan menjadi 2 (dua) yaitu :

\section{a. Data Kualitatif}

Menurut Sugiyono (2015:252) Data kualitatif adalah data yang berbentuk kata, kalimat,gambar, foto, bagan, dan perasaan.

Data kualitatif yang digunakan dalam penulisan Tugas Akhir ini berupa gambaran umum Badan Pengelola
Pendapatan Daerah Provinsi Jawa Tengah, lokasi, struktur organisasi, tugas dan tanggungjawab masingmasing jabatan.

b. Data Kuantitatif

Menurut Sugiyono (2015:253) Data kuantitatif adalah data yang berbentuk angka, atau data kualitatif yang diangkakan (scoring).Data kuantitatif yang digunakan dalam penulisan Tugas Akhir ini berupa Laporan Realisasi Anggaran, Laporan Operasional, Neraca, dan dokumen pendukung pendapatan Retribusi Pemakaian Kekayaan Daerah.

\section{Metode Pengumpulan Data}

Dalam pengumpulan data yang dperlukan digunakan metode sebagai berikut:

a. Wawancara

Menurut Wahyu Purhantara (2010:80) Wawancara adalah proses percakapan dengan maksud untuk mengonstruksi mengenai orang, kejadian, kegiatan, organisasi, motivasi, perasaan dan sebagainya yang dilakukan dua pihak, yaitu pewawancara (intervewer) yang mengajukan pertanyaan kepada orang lain yang diwawancarai (interviewee). Dalam hal ini, penulis melakukan wawancara secara langsung dengan sumber data yang berhubungan yang menangani retribusi pemakaian kekayaan daerah pada Badan Pengelola Pendapatan Daerah Provinsi Jawa Tengah.Dalam wawancara, data yang ditanyakan berupa data mengenai gambaran umum perusahaan, tugas dan tanggungjawab masing-masing jabatan, Laporan Keuangan, dokumen pembantu yang berhubungan dengan retribusi pemakaian kekayaan daerah.

b. Studi Pustaka

Menurut Wiratno Sujarweni (2015:157) Studi pustaka dilakukan dengan mempelajari dan mengambil data dari literature terkait dan sumber-sumber lain yang dianggap dapat memberikan informasi mengenai suatu penelitian.Dalam hal ini, penulis 
mengumpulkan data dengan melengkapi peraturan daerah, peraturan gubernur, undang-undang yang berhubungan dengan retribusi daerah khusunya retribusi pemakaian kekayaan daerah.

\section{Metode Penulisan}

Metode penulisan yang digunakan dalam penelitian ini adalah :

a. Metode Deskripsi

Menurut Alek dan Achmad (2010:184)

Metode deskripsi adalah metode penulisan yang menggambarkan bentuk objek pengamatan, rupanya, sifatnya, rasanya, atau coraknya termasuk golongan pemerian. Metode ini digunakan untuk menggambarkan gambaran umum Badan Pengelola Pendapatan Daerah Provinsi Jawa Tengah, visi dan misi, struktur organisasi, serta tugas-tugasnya.

b. Metode Eksposisi

Menurut Alek dan Achmad (2010:184)

Metode eksposisi adalah metode Penulisan yang bertujuan untuk memberikan informasi, penjelasan, keterangan, atau pemahaman termasuk golongan pemaparan.
Metode ini digunakan untuk menjelaskan tentang penerapan basis akrual pada pengakuan, pengukuran, penyajian dan pengungkapan pendapatan Retribusi Pemakaian Kekayaan Daerah pada Badan Pengelola Pendapatan Daerah Provinsi Jawa Tengah.

\section{PEMBAHASAN}

Pada dokumen pendukung SKRD dan TBP sudah benar seperti diatas yakni diuraikan setiap transaksi dan tidak digabung, sedangkan pada dokumen pendukung STS terjadi penggabungan transaksi yakni Sewa Tanah dan Bangunan sebesar Rp 22.927.500,00 yang seharusnya diperinci per transaksinya, dan Sewa Ruang Fotocopy\& Sewa Ruang Kantin sebesar Rp 27.576.000,00 dari transaksi sewa ruang fotocopy sebesar $R p$ 6.336.000 dan sewa ruang kantin sebesar Rp 21.248.000.berikut jurnal yang seharusnya pada saat penyetoran kas ke kas umum daerah atau terbit Surat Tanda Setoran (STS): 
Tabel 2 Saat Penyetoran Kas Ke Kas Umum Daerah (Saat terbit STS)

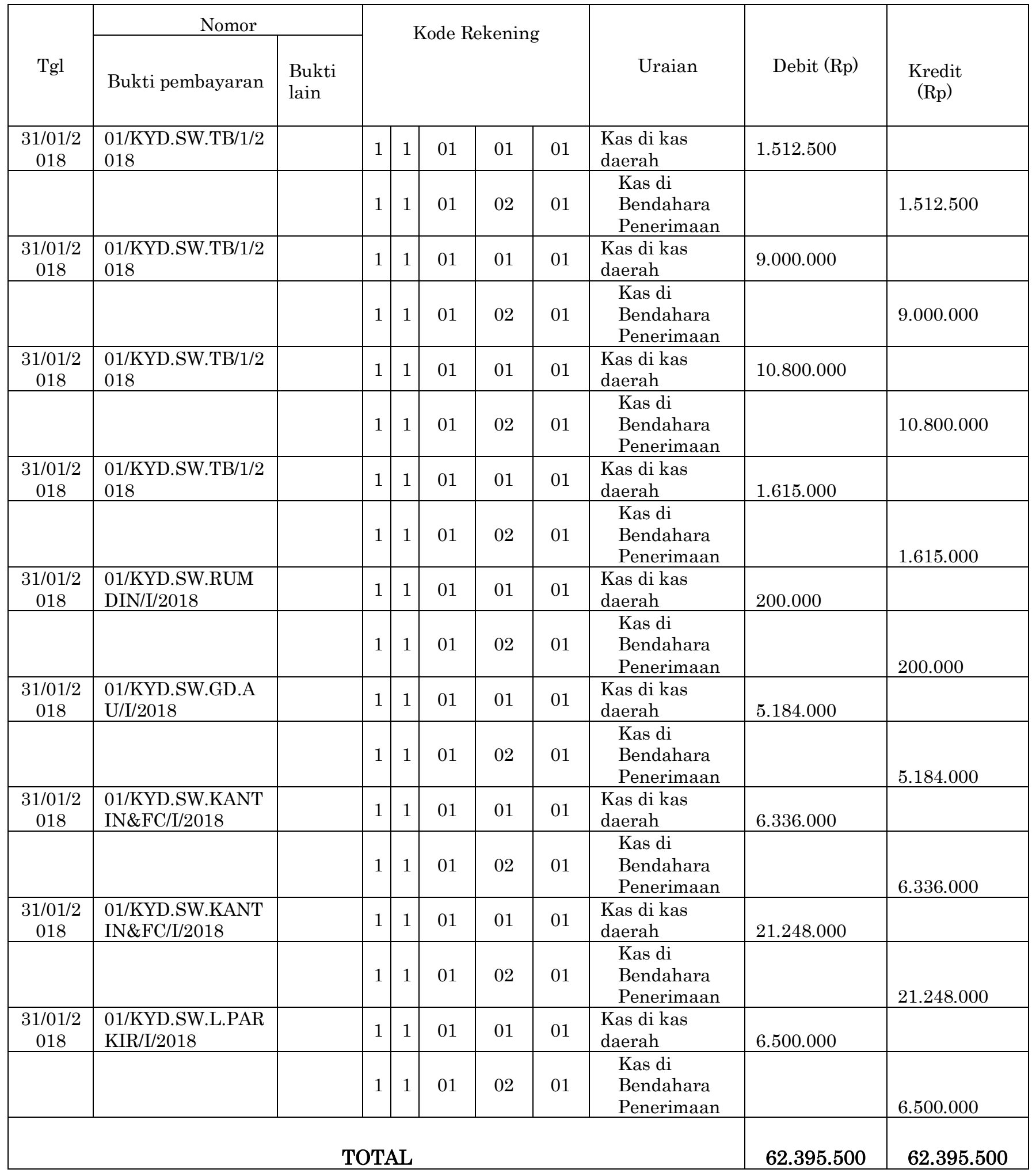




\section{Perlakuan Akuntansi Pendapatan Retribusi Pemakaian Kekayaan Daerah}

\section{Pengakuan Retribusi Pemakaian Kekayaan Daerah}

Penerapan pengakuan pendapatan retribusi pemakaian kekayaan daerah di Badan Pengelola Pendapatan Daerah Provinsi Jawa Tengah sebagai berikut :

1. Timbulnya hak atas pendapatan (earned)

Badan Pengelola Pendapatan Daerah mengakui saat timbulnyahak atas pendapatan yakni mengakui sebagai pendapatan meskipun belum diterima pembayaran dari wajib retribusi.Dalam hal ini berarti saat diterbitkannya Surat Ketetapan Retribusi Daerah (SKRD).Dengan menjurnal piutang retribusi (D) pada pendapatan retribusi (K).

2. Pendapatan direalisasi (realized) Pengakuan atas pendapatan direalisasi yakni mengakui pendapatan ketika benar-benar terjadi aliran masuk atau saat wajib retribusi melakukan pembayaran piutang retribusi secara tunai. Pada saat ini, diterbitkannya dokumen pendukung yaitu Tanda Bukti Pembayaran sebagai tanda bukti yang sah untuk selanjutnya menjadi dasar PPK SKPD untuk mengakui pendapatan dengan menjurnal kas dibendahara penerimaan (D) pada Piutang retribusi (K).

Pengakuan retribusi pemakaian kekayaan daerah sangat penting bagi Badan Pengelola Pendapatan Daerah Provinsi Jawa Tengah karena merupakan salah satu pendapatan yang dikelola dan sangat berpengaruh terhadap suatu Laporan Keuangan.

\section{Pengukuran Retribusi Pemakaian Kekayaan Daerah}

Terjadi perjanjian sewa berupa sewa ruang fotocopy yang beralamat di Jalan
MT Haryono Sidomulyo Ungaran Timur dengan luas bangunan $3 m \times 3 m=$ $9 \mathrm{~m}^{2}$.Besaran retribusi pemakaian kekayaan daerah dalam perjanjian disebutkan dipakai untuk fotocopy dengan jangka waktu selama 1 (satu) tahun sebesar Rp 3.240.000. Dalam perjanjian juga disebutkan tatacara pembayaran, hak dan kewajiban, jangka waktu, larangan, pembatalan perjanjian,dan lain sebagainya. Dalam pengukuran besaran retribusi pemakaian kekayaan untuk fotocopy menggunakan tarif sesuai dalam Peraturan Gubernur Nomor 20 Tahun 2015 yakni $R p 30.000 / m^{2}$. Berikut pengukuran besarannya:

Pengukuran : Satuan Pemakaian x Tarif Retribusi

$$
\text { : } 9 \mathrm{~m}^{2} \mathrm{x} \operatorname{Rp} 30.000
$$

: Rp 270.000/bulan

Besaran

Retribusi Setahun: Rp 270.000 x 12 bulan

$$
\text { : Rp 3.240.000 }
$$

\section{KESIMPULAN}

Berdasarkan pembahasan yang telah dilakukan, maka dapat disimpulkan bahwa :

1. Pengakuan pendapatan Retribusi Pemakaian Kekayaan Daerah dengan basis akrul yaitu pendapatan diakui saat timbulnya hak dengan diterbitkannya Surat Ketetapan Retribusi Daerah (SKRD) dan Pendapatan direalisasiyaitu saat adanya aliran masuk sumber daya ekonomi dengan bukti Tanda Bukti Pembayaran (TBP). Sedangkan untuk pengukuran pendapatan retribusi pemakaian kekayaan daerah telah sesuai dengan tarif yang ada di Peraturan yakni dalam Peraturan Gubernur Nomor 20 
Tahun 2015. Pengukuran Retribusi Pemakaian Kekayaan Daerah dilakukan melalui satuan pemakaian dikalikan tarif objek sesuai dengan Peraturan Gubernur Nomor 20 Tahun 2015. Pendapatan Retribusi pemakaian kekayaan daerah disajikan dan diungkapkan dalam 3 (tiga) laporan yakni Laporan Operasional, Laporan Realisasi Anggaran, dan Neraca.

2. Dokumen pendukung yang digunakan oleh Badan Pengelola Pendapatan Provinsi Jawa Tengah dalam penggunaannya telah diproses manual dengan benar. Terbukti dalam penjurnalan di Jurnal Khusus telah dilakukan dengan benar, bahkan saat terjadi keterlambatan pembayaran juga telah dihitung dengan benar. Karena BPPD Provinsi Jawa Tengah menggunkan Government Resource Management System (GRMS) yang memindahkan dari manual ke GRMS oleh sebab itu terjadi beberapa masalah, salah satunya yakni saat input jurnal khusus yang bersumber dari dokumen pendukung. Dalam menginput semua transaksi SKRD dan TBPke GRMS sudah secara rinci tiap transaksi tapi dalam penginputan saat penyetoran kas ke kas umum daerah (saat terbit STS) tidak dirinci per transaksi terjadi penggabungan transaksi. Dalam pencatatan pada GRMS dilakukan per transaksi,sehingga jurnal khusus daritiap dokumen pendukung dibuat 1(satu) tiap transaksi. Maka dalam pembuatan laporan rekap saat penyetoran kas tidak usah digabung, dibuat per transaksi saja mengikuti dokumen pendukung yakni saat terbit SKRD dan TBP.

\section{DAFTAR PUSTAKA}

Alek dan Achmad. 2011. Bahasa Indonesia

Untuk Perguruan Tinggi. Jakarta: Kencana Prenada Media Group.
Daerah Jawa Tengah. 2002. Retribusi Pemakaian Kekayaan Daerah. Peraturan Daerah Jawa Tengah Nomor 11 Tahun 2002.

Daerah Jawa Tengah. 2011. Retribusi Daerah.Peraturan Daerah Jawa Tengah Nomor 1 Tahun 2011.

Daerah Jawa Tengah. 2014. Perubahan Atas

Peraturan Derah Provinsi Jawa Tengah Nomor 1 Tahun 2011 Tentang Retribusi Daerah Jawa Tengah.Peraturan Daerah Provinsi Jawa Tengah Nomor 10 Tahun 2014.

Erlina, dkk. 2015. Akuntansi Keuangan Daerah. Jakarta: Salemba Empat.

Gubernur Jawa Tengah. 2014. Kebijakan dan Sistem Akuntansi Pemerintah Daerah Provinsi Jawa Tengah. Peraturan Gubernur Jawa Tengah Nomor 45 Tahun 2014.

Gubernur Jawa Tengah. 2015. Perubahan

Kedua Atas Peraturan Gubernur Nomor 24 Tahun 2014 Tentang Perubahan Tarif Retribusi Daerah.Peraturan Gubernur Jawa Tengah Nomor 20 Tahun 2015.

Gubernur Jawa Tengah. 2016. Kebijakan

Akuntansi Pemerintah Daerah Provinsi Jawa Tengah. Peraturan Gubernur Jawa Tengah Nomor 120 Tahun 2016.

Komite Standar Akuntansi Pemerintahan.

2012. Peraturan Pemerintah Republik Indonesia Nomor 71 Tahun 2010 Tentang Standar Akuntansi Pemerintahan. Jakarta: Salemba Empat. 
Purhantara, Wahyu. 2010. Metode Penelitian Untuk Bisnis. Yogyakarta: Graha Ilmu.

Sugiyono. 2015. Metode Penelitian \& Pengembangan. Bandung:Alfabeta.

Sukardi. 2011. Metode Penelitian

Pendidikan. Jakarta:PT. Bumi Aksara.

Tanjung, Abdul Hafiz. 2015. Akuntansi Keuangan Daerah Berbasis Akrual Untuk SKPD.Bandung: Alfabeta.
Undang-Undang nomor 33 Tahun 2004

Tentang Perimbangan Keuangan Antara Pusat dan Pemerintah Daerah.

Undang-Undang Republik Nomor 28 Tahun2009 Tentang Pajak Daerah Dan Retribusi Daerah. Semarang:Duta Nasindo.

Wiranata, Sujarweni. 2015. Metodologi Penelitian. Yogyakarta:PT. Pustaka Baru Press. 